\title{
Quinolines and Macrolides Resistance-Associated Mutations in Chlamydia trachomatis in Women Endocervical Samples in the West Region of Cameroon
}

\author{
B. E. Djoumsie Gomseu, R. Dadwal, J.D.D. Tamokou, R. Yadav, \\ W. J. Takougoum Marbou, J.-R. Kuiate and S. Sethi
}

\section{ABSTRACT}

Chlamydia trachomatis infection is a public health problem worldwide. Although antibiotic resistance of this strict intracellular bacterium is rare, it is important to monitor the appearance of resistance genes to available efficient antibiotics. This study aimed to screen for mutations in some of these genes in C. trachomatis clinical isolates, which may be associated to resistance to quinolone and macrolide antibiotics. Thirty-five endocervical samples were collected from women aged between 18 and 49 in five district hospitals in the Western Region of Cameroon. The mutations in quinolones (parC and gyrA) and macrolides (L4, L22 and $23 \mathrm{~S}$ rRNA) resistance domains were detected by PCR followed by sequencing on positive samples to $C$. trachomatis. The overall mutation rate for the studied genes was $60 \%$ in the studied samples. Seven $(20 \%)$ and twelve (34\%) samples presented mutations in the parC and gyrA gene respectively. Mutations in $\mathrm{L} 4(11.42 \%)$ and $\mathrm{L} 22(60 \%)$ were detected in ours samples, while no mutation was found in $23 \mathrm{~S}$ rRNA gene. Seven clinical samples $(\mathbf{2 0} \%)$ presented mutations to both macrolide and quinolone resistance genes. This study revealed a relatively high rate of mutations in the resistance genes to macrolides and quinolones in $\boldsymbol{C}$. trachomatis in the West Cameroon. This rate of mutation calls for the competent authorities for better surveillance of $\boldsymbol{C}$. trachomatis infection in West Cameroon to avoid a sudden increase in resistance to antibiotics in the years to come.

Keywords: Chlamydia trachomatis, genes, mutations, resistance, macrolide, quinolone.

Submitted: September 18, 2021

Published: October 30, 2021

ISSN: $2593-8339$

DOI: $10.24018 /$ ejmed.2021.3.5.1071

B. E. Djoumsie Gomseu

University of Dschang, Dschang, Cameroon.

(e-mail: emmanuelgomseu@gmail.com) R. Dadwal

Post Graduate Institute of Medical Education and Research, Chandigarh, India.

(e-mail: rajneesh.dadwal@hotmail.com) J.D.D. Tamokou

University of Dschang, Dschang, Cameroon.

(e-mail: jtamokou@yahoo.fr)

R. Yadav

Post Graduate Institute of Medical Education and Research, Chandigarh, India.

(e-mail: pgi.rky@gmail.com)

W. J. Takougoum Marbou

University of Dschang, Dschang,

Cameroon.

(e-mail: marboutakougoum@yahoo.fr)

J.-R. Kuiate*

University of Dschang, Dschang,

Cameroon.

(e-mail: jrkuiate@yahoo.com)

S. Sethi

Post Graduate Institute of Medical

Education and Research, Chandigarh, India.

(e-mail: sunilsethi10@hotmail.com)

*Corresponding Author

\section{INTRODUCTION}

Chlamydia trachomatis is the most common sexually transmitted disease and causative agent of a variety of disease situations including ocular trachoma leading to blindness; oculo-genital diseases causing infertility, pelvic inflammatory disease; reactive arthritis in adults; lymphogranuloma venereum and perinatal infections [1]. C. trachomatis infection affects 92 million people around the world each year [2]. This infection and their sequelae are major public health problems, resulting in high morbidity and economic losses linked to low worker performance and treatment costs [3]. These costs increase significantly when the disease is not diagnosed and treated on time, leading to complications [4]. The first line antibiotic used for the treatment of $\mathrm{C}$. trachomatis infection include doxycycline, erythromycin, azithromycin, ciprofloxacin, and ofloxacin [5], [6]. In women, bacteriological cure does not confirm anatomical and functional cure. Indeed, irreversible tubal or pelvic lesions may have formed and persist after eradication of microbial agents.

Chlamydia trachomatis, which exhibits natural resistance to antibiotics active on the cell wall such as $\beta$-lactams or glycopeptides, is sensitive to only a few antibiotics which 
target the bacterial cell wall. On the other hand, this strict intracellular bacterium is more sensitive to antibiotics which have good cellular penetration, which explains why macrolides (erythromycin, azithromycin), tetracyclines (doxycycline) and quinolones (ciprofloxacin, ofloxacin) are generally used for the treatment depending on clinical situations [7], [8]. Some cases of azithromycin treatment failure for $\mathrm{C}$. trachomatis infections have been noted and are explained by high MICs and by a positive correlation between MICs and C. trachomatis loads [9].

The principal targets of the quinolones are DNA gyrase and topoisomerase IV [10]. Quinolones act on bacteria by inhibiting these two enzymes which have two different subunits, GyrA/GyrB and ParC/ParE. Quinolone resistance most commonly occurs after point mutations in quinolone resistance determining regions (QRDRs) of subunit genes [11]. The resistance of various microorganisms to macrolides is often associated with mutations in ribosomal protein genes, particularly in L4 and L22, as well as with mutations in the peptidyl transferase region of the $23 \mathrm{~S}$ rRNA gene [12]. At present, antimicrobial resistance is a barrier to the effective treatment of a growing range of infections and requires actions, especially as we face the emergence of new resistance mechanisms that are rapidly spreading around the world [13]. It is necessary to update the recommendations on antibiotic treatment due to the development of resistance to the molecules generally used. To achieve this objective, the response of a germ or a group of germs to an antibiotic must be known in time and space to adapt the therapies to updated data. This is all the truer as the epidemiological data are constantly changing. In a recent study conducted in five hospitals in the West Cameroon region, using PCR detection, we found that the prevalence of $\mathrm{C}$. trachomatis infection was $11.5 \%$ and the circulating serotypes were found to be mainly D (49\%), E (29.4\%) and G (21.6\%) (Unpublished results). As this prevalence can be considered high, we are wondering whether in the same area, resistant strains of C. trachomatis are circulating amount women due to mutations on some genes in the bacteria, which could complicate the management of patients and the epidemiological control of the disease. Although antibiotic resistance in C. trachomatis is rare, it is important to stay alert to detect any changes in the sensitivity of this microorganism to prescribed antibiotics. The objective of this study was to detect mutations in certain genes of $\mathrm{C}$. trachomatis and its distribution in West Cameroon, which may be associated with the resistance of this microorganism to antibiotics quinolone and macrolide families.

\section{Methodology}

\section{A. Participants}

This study was conducted on 35 endocervical swab samples positive for $C$. trachomatis PCR amplification of the following genes: parC, gyrA, L4, L22 and 23S rRNA. Theses samples were collected from women in five district hospitals of the West Cameroon region between May 2018 and November 2019 as follows: Dschang (09), Bafang (03), Mbouda (13), Bafoussam (05) and Bangangté (05) (Fig. 1). The participants involved in this study were 18-49 years old.
They came to the hospital seeking prenatal consultation, prenuptial consultation or contraception. This study was conducted with ethical clearances obtained from the Cameroon National Committee for Ethics in Human Health (2018/05/1022/CE/CNERSH/ SP) and from Post Graduate Institute of Medical Education and Research, Chandigarh (PGI/IEC/2020/001586). An administrative authorization was also obtained from the West Regional Delegation of Public Health and from each hospital. Persons who fulfilled the following criteria were included: be a volunteer, provided a signed informed consent, be more than 18 years, be sexually active, must not have sexual intercourse for at least 48 hours, not menstruating.

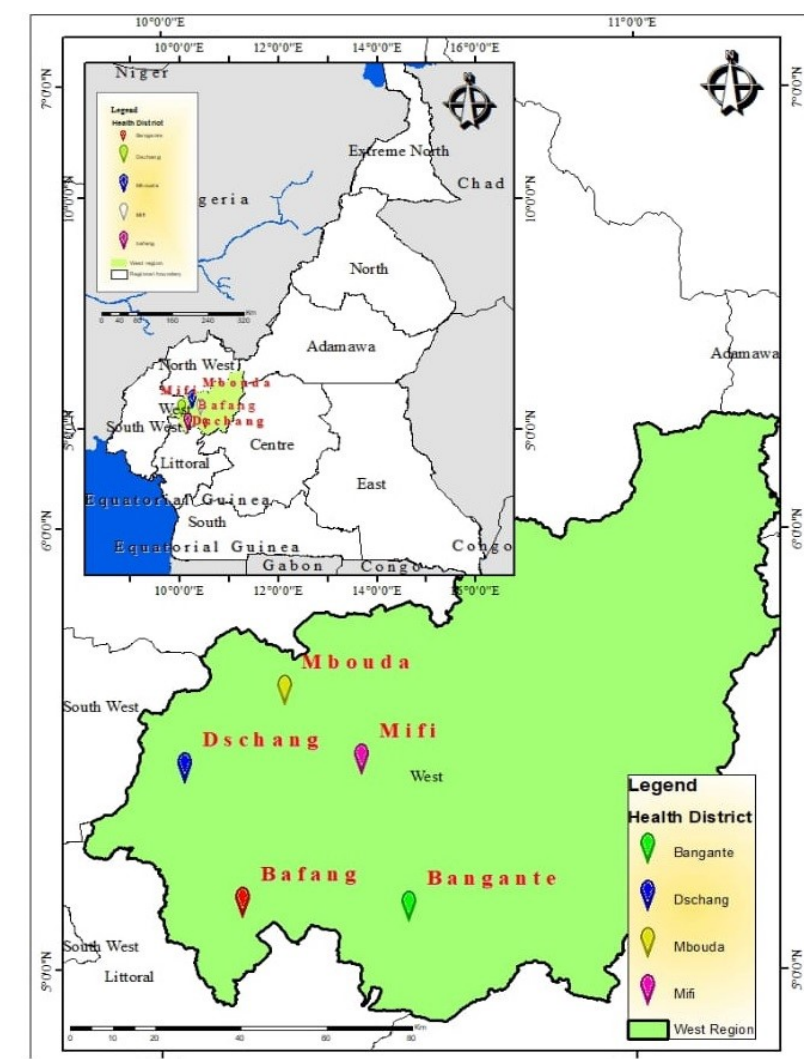

Fig. 1. Map representing the West Region of Cameroon and showing the study areas.

\section{B. Procedure}

The endocervical swabs samples were obtained from women using a non-lubricated speculum and an abrasive swab of the "bactopick" type by the trained health care workers at the study sites. The swab was then placed into a storage tube containing $1 \mathrm{ml}$ of sterile saline $(0.9 \% \mathrm{NaCl})$ and stored at $-20^{\circ} \mathrm{C}$ until further processing [14].

The obtained endocervical samples were submitted to DNA extraction, using the QIAamp mini kit according to the manufacturer's instructions [15]. Briefly, the tubes containing the endocervical sample were removed from the freezer, left at room temperature for one hour and centrifuged at $15,000 \mathrm{rpm}$ for 10 minutes. The supernatant was removed while preserving the pellet, ATL buffer and Proteinase K were added to it and it was homogenized with the help of a vortex mixer (iwix-VT Neuation), and then incubated at $56{ }^{\circ} \mathrm{C}$ for 3 hours while homogenizing during incubation. Once the incubation was complete, $200 \mu \mathrm{L}$ of AL buffer was added and incubated at $70{ }^{\circ} \mathrm{C}$ for 10 minutes. Then $200 \mu \mathrm{L}$ 
absolute ethanol was added and homogenized. The mixture was then transferred into minicolumns and centrifuged at $8,000 \mathrm{rpm}$ for 1 minute. After extensive washing with $500 \mu \mathrm{L}$ of buffer AW1 and then with $500 \mu \mathrm{L}$ of AW2, $50 \mu \mathrm{L}$ of buffer $\mathrm{AE}$ was added, left at room temperature for 5 minutes. The tubes were centrifuged, and the extracted DNA was stored at $-20{ }^{\circ} \mathrm{C}$ until further analysis. Nucleic acids concentration was estimated after the extraction by measuring the absorbance at $260 \mathrm{~nm}$ using a Nanodrop spectrophotometer (Thermo Scientific NanoDrop 2000 Spectrophotometer. Then, the ratio of spectrophotometric absorbance of extracted sample at $260 \mathrm{~nm}$ to that of $280 \mathrm{~nm}$ was used to determine the purity of DNA. A260/A280 ratio $\geq 1.8$ indicates pure DNA extraction [16].

The extracted DNA was amplified using Cryptic plasmic primer KL1-KL2 (KL1: 5'TCCGGAGCGAGTTACGAAGA-3'; KL2: 5'AATCAATGCCCGGGATTGGT-3') [17] and MOMP primer (forward: 5'-CCT GTG GGG AAT CCT GCT GAA3'; Reverse: 5' GTC GAA AAC AAA GTC ACC ATA GTA $\left.3^{\prime}\right)$ [18]. The amplification reaction was performed in a final volume of $25 \mu \mathrm{l}$ containing 1X PCR buffer (10 mMTris-HCl; $50 \mathrm{mMKCl} ; 1.5 \mathrm{mM} \mathrm{MgCl} 2), 0.5 \mu \mathrm{M}$ of each pair of primer, $200 \mu \mathrm{M}$ of dNTPs; $1 \mathrm{U}$ of Taq DNA polymerase, $5 \mu 1$ of DNA. The PCR conditions consisted of initial denaturation step at $95^{\circ} \mathrm{C}$ for 10 minutes; 50 cycles of $95^{\circ} \mathrm{C}$ for 30 seconds, $60{ }^{\circ} \mathrm{C}$ for 1 minute, and $72{ }^{\circ} \mathrm{C}$ for 1 minute; and a final extension at $72{ }^{\circ} \mathrm{C}$ for 7 minutes. The amplicons were electrophoresed through an agarose gel $2 \%$ and the visualized on a UV transilluminator (Agilent Technologies Sure Cycle 8800).

All PCRs were performed in a final volume of $25 \mu \mathrm{L}$ containing 1X PCR buffer (10 mMTris- $\mathrm{HCl} ; 50 \mathrm{mMKCl}$; $1.5 \mathrm{mM} \mathrm{MgCl} 2$ ), $0.5 \mu \mathrm{M}$ of each pair of primer (Table 1) [19,20], $200 \mu \mathrm{M}$ of dNTPs; $1 \mathrm{U}$ of Taq DNA polymerase and $5 \mu \mathrm{l}$ of DNA. The PCR conditions were: $95^{\circ} \mathrm{C}$ for 10 minutes; 40 cycles of $95^{\circ} \mathrm{C}$ for 1 minute, $56^{\circ} \mathrm{C}$ and $60^{\circ} \mathrm{C}$ for 23 rRNA for 1 minute, $72{ }^{\circ} \mathrm{C}$ for 2 minutes, and a final extension at 72 ${ }^{\circ} \mathrm{C}$ for 7 minutes.

PCR products were sequenced in a BigDye Terminator sequencing kit (Applied Biosystems, USA) on a 3500 Dx sequencing machine available in the Department of Medical Microbiology, PGIMER, Chandigarh. The obtained nucleotide sequences of parC, gyrA, L4, L22 and 23S rRNA were compared to the nucleotide sequences in the GenBank nucleotide sequence databases to detect any modification. The following accession numbers were used: AF044267 for the gyrA sequences, AF044268 for the parC sequences, AE001273 for the ribosomal protein L4 and AE001273 for the ribosomal protein $L 22$ and NR103960 for the 23S rRNA.

TABLE I: PRIMERS USED FOR PCR AMPLIFICATION AND SEQUENCING

\begin{tabular}{ccc}
\hline \hline Primer target & Sequence 5' to 3' & Size (bp) \\
\hline \hline CT gyrA F & AAGGACTCTCGTTAGAGTCTC & \multirow{2}{*}{362} \\
CT gyrA R & CGATRCCTGAGGAGCCATTAC & \\
CT parC F & GATACAGAAACCCTSGACACAC & \multirow{2}{*}{201} \\
CT parC R & CATGGAAGGTCATGAGATCCG & \\
CT L4 protein F & GAAGTTTGAATTGCCTGATGC & \multirow{2}{*}{250} \\
CT L4 protein R & GGCTTAGGACCGAAAACAATC & \\
CT L22 protein F & AGCTGCAGGATTGATGAGAAA & \multirow{2}{*}{230} \\
CT L22 protein R & GTTAGATGACTCGTGCGCTTC & \\
CT 23S rRNA F & AAGTTCCGACCTGCACGGTGG & \multirow{2}{*}{725} \\
CT 23S rRNA R & TCCATTCCGGTCCTCTCGTAC & \\
\hline \hline bp: base pair. & &
\end{tabular}

bp: base pair.

\section{RESUlTS}

Obtained PCR products of parC, gyrA, L4, L22 and $23 S$ $r R N A$ genes (Fig. 2) were sequenced to detect mutations possibly associated to quinolone and macrolides resistance in C. trachomatis. Mutations were identified in $21(60 \%)$ of the 35 analysed samples and varied with the genes in consideration.

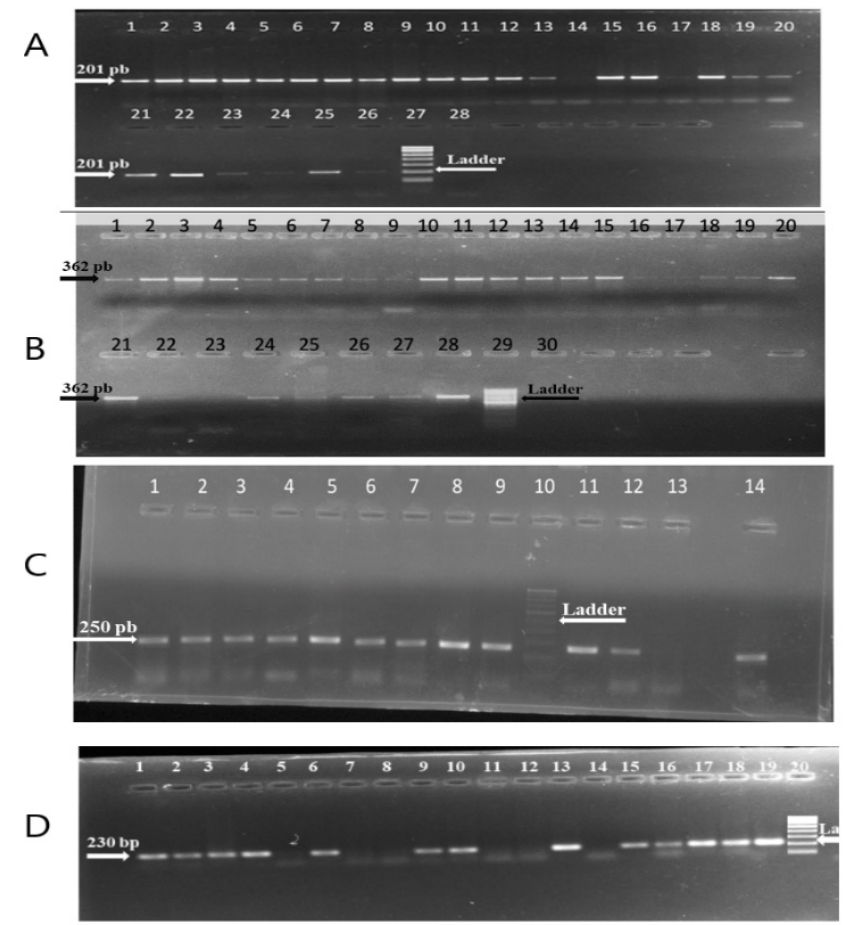

Fig. 2. Gel electrophoresis profiles of PCR amplified from A) parC gene: positive samples showed a $201 \mathrm{bp}$ band as positive control (lane 20 and 26); negative control lane 28.

B) gyrA gene: positive samples showed a $362 \mathrm{bp}$ band as the positive controls (lane 20 and 28), negative control (lane 29.

C) PCR amplification of L22 protein from C. trachomatis-positive patients: lane 1 to $9,11,12$ (250bp), positive samples; lane 14, positive control; lane 13, negative control; lane 10, DNA ladder (100bp)

D) PCR amplification of $L 4$ protein from C. trachomatis-positive patients: lane 1 to $4,6,9,10,13,15,16,17,18$ (230bp), positive samples; lane 19, positive control; lane 14, negative control; lane 20, DNA ladder (100bp)

These mutations associated to quinolones resistance were detected in 7 (20\%) samples for parC gene and in 12 (34\%) for gyrA gene. Sequence analysis of ParC gene showed that these mutations are located at position 83, resulting in a substitution of an Arginine by Glycine (01 sample in Dschang and 01 sample in Bafoussam) and at position 94 resulting in substitution of Threonine by Alanine (01 in Dschang, 02 in Mbouda and 02 in Bangangté) (Table II). On gyrA gene, 06 mutations were identified respectively at position 137 characterised by substitution of Glutamine by Leucine ( 01 sample in Bafang and 01 sample in Mbouda); at position 148, substitution of Histidine with Arginine (01 Dschang), at position 136, substitution of Threonine with Isoleucine (01 at Mbouda); at position 98, substitution of Leucine with Arginine (01 in Dschang and 03 in Mbouda); at position 167, substitution of Isoleucine with Threonine (01 in Bafang and 01 in Mbouda) and at position 174, substitution of Valine with Alanine (02 in Bafang) (Table II).

No mutation was detected in 23S rRNA in all the samples analysed. Four (11.42\%) samples showed mutations in ribosomal protein $L 4$ gene while $21(60 \%)$ samples showed 
mutations in $L 22$ gene. The mutation observed in the $L 4$ gene was at position 129 , resulting in replacement of Glutamine by Lysine (01 in Bafoussam, 01 in Dschang and 02 in Bafang) in four clinical samples (Table 2). In the gene L22, mutations were observed at position 77 , substitution of Valine by Alanine (01 in Bafoussam, 06 in Dschang, 01 in Bafang, 07 in Mbouda and 07 in Bangangté); at position 52, replacement of Arginine by Cysteine (05 in Dschang, 02 in Bafang, 05 in Mbouda and 02 in Bangangté); at position 65, replacement of Glycine by Serine (08 in Dschang, 01 in Bafang, 07 in Mbouda and 02 in Bangangté) (Table II).

Some mutations were observed simultaneously in genes responsible for resistance to quinolones and macrolides. Seven samples $(20 \%)$ were concerned: 02 with mutations in parC, gyrA and $L 4$ genes (01 in Dschang and 01 in Mbouda); 03 mutations with mutations in both gyrA and $L 22$ genes (01 in Dschang, 01 in Bafang and 01 in Mbouda); 01 with mutation in parC and $L 22$ genes (01 in Bafang) and 01with mutation in parC and $L 22$ genes in Bafang (Table II).

TABLE II: DISTRIBUTION OF MUTATIONS IN PARC, GYRA, $L 4$ AND $L 22$ GENES AND AMINO ACID CHANGES IN C. TRACHOMATIS CliniCAL SAMPLE IN DisTRICT HOSPITALS IN WEST CAMEROON

\begin{tabular}{|c|c|c|c|c|c|c|c|c|c|}
\hline \multicolumn{5}{|c|}{ Resistance to quinolones } & \multicolumn{5}{|c|}{ District hospitals } \\
\hline Mutation & $\mathrm{NC}$ & $\mathrm{AC}$ & $\mathrm{p}$ & $\begin{array}{c}\mathrm{n} \\
(\%)\end{array}$ & $\mathrm{b}$ & $\mathrm{d}$ & $\mathrm{f}$ & $\mathrm{m}$ & $\mathrm{t}$ \\
\hline \multirow{2}{*}{$\begin{array}{c}\text { parC } \\
\text { mutation }\end{array}$} & $\mathrm{A} \rightarrow \mathrm{G}$ & $\mathrm{T}$ to $\mathrm{A}$ & 94 & $\begin{array}{c}5 \\
(14.28)\end{array}$ & 0 & 1 & 0 & 2 & 2 \\
\hline & $\mathrm{A} \rightarrow \mathrm{G}$ & $\mathrm{R}$ to $\mathrm{G}$ & 83 & $\begin{array}{c}2 \\
(5.71)\end{array}$ & 1 & 1 & 0 & 0 & 0 \\
\hline \multirow{6}{*}{$\begin{array}{c}\text { gyrA } \\
\text { mutation }\end{array}$} & $\mathrm{A} \rightarrow \mathrm{T}$ & Q to $\mathrm{L}$ & 137 & $\begin{array}{c}2 \\
(5.71)\end{array}$ & 0 & 0 & 1 & 1 & 0 \\
\hline & $\mathrm{C} \rightarrow \mathrm{T}$ & T to I & 136 & $\begin{array}{c}1 \\
(2.86)\end{array}$ & 0 & 0 & 0 & 1 & 0 \\
\hline & A & $\mathrm{H}$ to $\mathrm{R}$ & 148 & $\begin{array}{c}1 \\
(2.86)\end{array}$ & 0 & 1 & 0 & 0 & 0 \\
\hline & $\mathrm{C} \rightarrow \mathrm{T}$ & $\mathrm{L}$ to $\mathrm{R}$ & 98 & $\begin{array}{c}4 \\
(11.43)\end{array}$ & 0 & 1 & 0 & 3 & 0 \\
\hline & $\mathrm{T} \rightarrow \mathrm{A}$ & I to $\mathrm{T}$ & 167 & $\begin{array}{c}2 \\
(5.71)\end{array}$ & 0 & 0 & 1 & 1 & 0 \\
\hline & $\mathrm{T} \rightarrow \mathrm{C}$ & $\mathrm{V}$ to $\mathrm{A}$ & 174 & $\begin{array}{c}2 \\
(5.71) \\
\end{array}$ & 0 & 0 & 2 & 0 & 0 \\
\hline \multicolumn{10}{|c|}{$\begin{array}{l}\text { Resistance to macrolides } \\
\end{array}$} \\
\hline $\begin{array}{c}\text { L4 } \\
\text { mutation }\end{array}$ & $\mathrm{C} \rightarrow \mathrm{A}$ & $\mathrm{Q}$ to $\mathrm{K}$ & 129 & $\begin{array}{c}4 \\
(11.42)\end{array}$ & 1 & 1 & 2 & 0 & 0 \\
\hline \multirow{3}{*}{$\begin{array}{c}\text { L22 } \\
\text { mutation }\end{array}$} & $\mathrm{G} \rightarrow \mathrm{A}$ & $\mathrm{G}$ to $\mathrm{S}$ & 52 & $\begin{array}{c}14 \\
(40)\end{array}$ & 0 & 5 & 2 & 5 & 2 \\
\hline & $\mathrm{C} \rightarrow \mathrm{T}$ & $\mathrm{R}$ to $\mathrm{C}$ & 65 & $\begin{array}{c}18 \\
(51.42)\end{array}$ & 0 & 8 & 1 & 7 & 2 \\
\hline & $\mathrm{T} \rightarrow \mathrm{C}$ & $\mathrm{V}$ to $\mathrm{A}$ & 77 & $\begin{array}{c}19 \\
(54.29) \\
\end{array}$ & 1 & 6 & 1 & & 7 \\
\hline \multicolumn{10}{|c|}{ Multiple Resistance to quinolones and macrolides } \\
\hline & Mutation & & \multirow{2}{*}{\multicolumn{2}{|c|}{$\begin{array}{c}\mathrm{n}(\%) \\
3(8.57)\end{array}$}} & 1 & 2 & 3 & 4 & 3 \\
\hline \multicolumn{3}{|c|}{ gyrA and L22 mutation } & & & 0 & 1 & 1 & 1 & 0 \\
\hline \multicolumn{3}{|c|}{ gyrA, parC and L22 mutation } & \multicolumn{2}{|c|}{$2(5.71)$} & 0 & 1 & 0 & 1 & 0 \\
\hline \multicolumn{3}{|c|}{$\begin{array}{l}\text { parC and L4 mutation } \\
\text { parC and L22 mutation }\end{array}$} & \multicolumn{2}{|c|}{$\begin{array}{l}1(2.85) \\
1(285)\end{array}$} & 0 & 0 & 0 & 0 & \\
\hline
\end{tabular}

b: Bafoussam; d: Dschang; f: Bafang; m: Mbouda; t: Banganté. $\mathrm{n}(\%)$ : number of sample with mutation (percentage of the 35 sample analysed): NC: Nucleotide change; AC: Amino acid change.

\section{DISCUSSION}

Quinolone resistance results from mutations in genes encoding DNA gyrase and topoisomerase IV, which are the main targets of these antibiotics [10]. Only 02 mutations $(5.71 \%)$ were detected on the parC gene while 06 were detected on gyrA gene (17.64\%). These mutation rates are high when compared to $0.66 \%$ and $2.66 \%$ respectively for parC and gyrA obtained for 300 endocervical samples analyzed in Iran [1]. Mutations identified in the quinolone resistance determining regions (QRDR) in this study were as follow: Arg83Gly, Thr94Ala, Ile167Thr, Val174Ala, Leu98Arg, Thr136Ile, Gln137Leu, and His148Arg in parC and gyrA genes. Mutations identified in L4 and L22 genes includes Gly52Ser, Arg65Cys, Val77Ala, and Gln129Lys. The amino acid changes observed in this study were the same as those described by Torabizadeh et al., Takashi et al. and Misyurina et al. [1], [19], [20]. But in some of our samples, these mutations differ in their positions compared to those described by these authors and could be due to the presence of endemic strains of $C$. trachomatis in the West Cameroon region or Cameroon in general. Quinolone resistance is explained by point mutations in the region determining resistance to these antibiotics and in $C$. trachomatis, this mutation mainly concerns the gyrA gene [11] as observed in the present study. Some authors attribute these mutations to prolonged exposure of the microorganism to subinhibitory concentrations of these antibiotics [21]. The level of selfmedication in Cameroon is very high and could justify the rates of mutations observed [22].

In accordance with the results of Vica et al. no mutation was observed in 23S rRNA gene [23]. However, Misyurina et al. described in 2004, samples with mutations in the peptidyl transferase region of the 23S rRNA gene in $C$. trachomatis [20]. Resistance to antibiotics of the macrolide family is mainly due to mutations in ribosomal proteins L4 and L22 [12]. As demonstrated by Misyurina et al. the mutations that we observed with macrolides were reside in a nonconserved region of the L22 gene in C. trachomatis, which is the case for several other microorganisms. In the present study, although the number of mutations was low, the number of samples containing them was relatively high, 25 samples over 35 .

Although the number of mutations on the studied genes were relatively low, their rate in our samples may be considered high. This may be explained by the predominance of probabilistic prescriptions of antibiotics in the hospitals surveyed rather than based on antibiograms. This is due to a lack of adequate infrastructure and / or qualified laboratory personnel. Elsewhere, self-medication and street drugs may have contributed to this situation, the health-care system in the country being relatively weak [22].

Mutations in resistance genes to both quinolones and macrolides were observed in 7 samples in 3 of 5 district hospitals (Bangangté, Mbouda and Bafang). This could therefore represent a probable alert of emerging multidrug resistance to $C$. trachomatis in the west region of Cameroon. In fact, Jyoti et al. and Jones et al. have described in the USA, C. trachomatis isolates resistant to both doxycycline, azithromycin and ofloxacin on the one hand and on the other hand resistant to tetracycline associated with multidrug resistance to doxycycline, minocycline, erythromycin, clindamycin, and sulfamethoxazole respectively [24], [25].

\section{CONCLUSION}

This work uncovered few mutations in the samples analysed and the rate of these mutations potentially 
associated to resistance to quinolones and macrolides was high $(60 \%)$. Also, some cases of multidrug resistance were identified. These results suggest that special attention should be paid to the surveillance of $C$. trachomatis infection in West Cameroon to avoid the occurrence of multi-resistance to antibiotics in the population.

\section{ACKNOWLEDGEMENTS}

Mr. Boris Emmanuel Djoumsie Gomseu like to acknowledge the TWAS and DBT for DBT-TWAS fellowship (Award of 2018 DBT-TWAS PG) and Post Graduate Institute of Medical Education and Research, Chandigarh, India for accepting him as fellow. He acknowledges the working facilities of Department of Microbiology, Post Graduate Institute of Medical Education and Research, Chandigarh, India.

\section{REFERENCES}

[1] R. Torabizadeh, "Point Mutations in gyrA and parC Genes of Quinolone-Resistant Chlamydia trachomatis in Iranian Women," International Journal of Pharmaceutical and Phytopharmacological Researchvol. 10, 96-100, 2020.

[2] WHO, "Growing antibiotic resistance forces updates to recommended treatment for sexually transmitted infections," https://www.who.int/news/item/30-08-2016-growing-antibioticresistance-forces-updates-to-recommended-treatment-for-sexuallytransmitted-infections, 2016.

[3] J. Hadfield, S. R. Harris, H. M. Seth-Smith, S. Parmar, P. Andersson, P. M. Giffard, J. Schachter, J. Moncada, L. Ellison, M. L. G. Vaulet, M. R. Fermepin, F. Radebe, S. Mendoza, S. Ouburg, S. A. Morré, K. Sachse, M. Puolakkainen, S. J. Korhonen, O. Sonnex, R. Wiggins, H. Jalal, T. Brunelli, P. Casprini, R. Pitt, C. Ison, A. Savicheva, E. Shipitsyna, R. Hadad, L. Kari, M. J. Burton, D. Mabey, A. W. Solomon, D. Lewis, P. Marsh, M. Unemo, I. N. Clarke, J. Parkhill and N. R. Thomson, "Comprehensive global genome dynamics of Chlamydia trachomatis show ancient diversification followed by contemporary mixing and recent lineage expansion," Genome Research 27, 1-10, 2017.

[4] H. W. Chesson, J. M. Blandford, T. L. Gift, G. G. Tao and K. L. Irwin, "The Estimated Direct Medical Cost of Sexually Transmitted Diseases Among American Youth, 2000," Perspectives on Sexual and Reproductive Health 36, 11-19, 2004.

[5] H. H. Hunter and J. A White, "Chlamydia trachomatis Biovar Genotyping and Treatment of Lymphogranuloma Venereum," Sexually Transmitted Disease 47, 253, 2020.

[6] Zikic, H. Schünemann, T. Wi, O. Lincetto, N. Broutet and N. Santesso, "Treatment of Neonatal Chlamydial Conjunctivitis: A Systematic Review and Meta-analysis," Journal of Pediatric Infectious Diseases 7, e107-e115, 2018.

[7] K. A. Workowski and G. A. Bolan, "Centers for Disease Control and Prevention. Sexually transmitted diseases treatment guidelines," Morbidity and Mortality Weekly Report Recommendations and Reports 64, 1-137, 2015.

[8] E. Lanjouw, S. Ouburg, H. J. de Vries and A. Stary, "2015 European guideline on the management of Chlamydia trachomatis infections," International Journal of STD\&AIDS 27, 333-48, 2016.

[9] Foschi, M. Salvo, R. Cevenini and A. Marangoni, "Chlamydia trachomatis antimicrobial susceptibility in colorectal and endocervical cells," Journal of Antimicrobial Chemotheraphy 73, 409-413, 2017.

[10] Q. J. George, "Mechanisms of resistance to quinolones," Clinical Infectious Disease 41, S120-S126, 2005.

[11] J. Rupp, W. Solbach and J. Gieffers, "Variation in the mutation frequency determining quinolone resistance in Chlamydia trachomatis serovars L2 and D," Journal of Antimicrobial Chemotherapy 61, 9194, 2008.

[12] H. Zhu, H-P. Wang, Y. Jiang, S-P. Hou, Y-J. Liu and A-Z. Liu, "Mutations in 23S rRNA and ribosomal protein L4 account for resistance in Chlamydia trachomatis strains selected in vitro by macrolide passage," International Journal of Andrology 42, 274-280, 2009.

[13] P. Fogue, G. Djeudong, G. Bouting, E. Aglago, G. Simo and S. Lueong,
"Molecular characterization of lower vaginal swabs for human papilloma virus in association with Chlamydia trachomatis infection in Cameroonian women," Journal of Infection and Public Health11, 314$320,2018$.

[14] S. B. Zaman, M. A. Hussain, R. Nye, V. Mehta, K. T. Mamun, N. Hossain, "A Review on Antibiotic Resistance: Alarm Bells are Ringing," The Cureus Journal of Medical Science 9, e1403.

[15] S. Paulos, M. Mateo, A. de Lucio, M. Hernández-de Mingo, B. Bailo, J. M. Saugar, G. A. Cardona, I. Fuentes, M. Mateo and D. Carmena, "Evaluation of five commercial methods for the extraction and purification of DNA from human faecal samples for downstream molecular detection of the enteric protozoan parasites Cryptosporidium spp., Giardia duodenalis, and Entamoeba spp.," Journal of Microbiology 127, 68-73, 2016.

[16] C. Payan, A. Ducancelle, M. H. Aboubaker, J. Caer, M. Tapia, A. Chauvin, D. Peyronnet, E. le Hen, Z. Arab, M. C. Legrand, A. Tran, E. Postec, F. Tourmen, M. Avenel, C. Malbois, M. A. de Brux, P. Descamps and F. Lunel, "Human Papillomavirus Quantification in Urine and Cervical Samples by Using the Mx4000 and Light Cycler General Real-Time PCR Systems," Journal of Clinical Microbiology 45, 897-901, 2007.

[17] M. Vineeta, A. Jyotsna, J. Amita, and K.V. Anoop, "Prevalence of genital Chlamydia trachomatis in women using PCR on urine specimen," Biomedical Research 21, 301-304, 2010.

[18] O. Mazen, I. E. Wafa, and A. E. Khalid, "Molecular Detection of Chlamydia trachomatis among Sexual Transmitted Infections patients in Khartoum," African Journal of Medicine and Medical Science 3(3), 2018.

[19] T. Deguchi, K. Hatazaki, S. Ito, H. Kondo, K. Horie, K. Nakane, K. Mizutani, T. Tsuchiya, M. Yasuda, S. Yokoi and M. Nakano, "Macrolide and fluoroquinolone resistance is uncommon in clinical strains of Chlamydia trachomatis," Journal of Infection and Chemotherapy 24, 610-614, 2018.

[20] O. Y. Misyurina, E. V. Chipitsyna, and Y. P. Finashutina, "Mutatiojn in a 23 rRNA gene of Chlamydia trachomatis associated with resistance to macrolide," Antimicrobial Agents and Chemotherapy 48, 13471349, 2004.

[21] Morrissey, H. Salman, S. Bakker, D. Farrell, C. M. Bébéar, G. Ridgway, "Serial passage of Chlamydia spp. in sub-inhibitory fluoroquinolone concentrations," Journal of Antimicrobial Chemotherapy 49, 757-61, 2002.

[22] Tantchou, "Petits pas d'Ethnographe, suivi de Portrait d'Hôpital," Habilitation à Diriger les Recherches, Université de Bordeaux, 2016.

[23] M. L. Vică, H. V. Matei, and C. V. Siserman, "Determining the Antibiotic Resistance of Bacterial Pathogens in Sexually Transmitted Diseases," Antimicrobial Agents 110-127, 2017.

[24] Somani, V. B. Bhullar, K. A. Workowski, and C. E. Farshy, C. M. Black, "Multiple Drug-Resistant Chlamydia trachomatis Associated with Clinical Treatment Failure," Journal of Infectious Diseases 181, 1421-7, 2000.

[25] R. B. Jones, D. P. B. Van, D. H. Martin, and M. K. Shepard, "Partial Characterization of Chlamydia trachomatis Isolates Resistant to Multiple Antibiotics," Journal of Infectious Diseases 162, 1309-1315, 1990. 